\title{
THE OCCURRENCE OF POLLEN OF SCIADOPITYACEAE LUERSS. THROUGH TIME
}

\author{
CHRISTA-CH. HOFMANN ${ }^{1, *}$, NYAMSAMBUU ODGEREL ${ }^{2}$, LEYLA J. SEYFULLAH ${ }^{1}$ \\ ${ }^{1}$ University of Vienna, Institute of Palaeontology, Althanstraße 14, 1090 Vienna, Austria; e-mail: christa.hofmann@univie.ac.at. \\ ${ }^{2}$ National University of Mongolia, School of Arts and Sciences, Ulaanbaatar, Mongolia. \\ ${ }^{*}$ corresponding author
}

Hofmann, Ch.-Ch., Odgerel, N., Seyfullah, L. J. (2021): The occurrence of pollen of Sciadopityaceae LuERSs. through time. Fossil Imprint, 77(2): 271-281, Praha. ISSN 2533-4050 (print), ISSN 2533-4069 (on-line).

\begin{abstract}
Here we present LM and SEM data of pollen of extant Sciadopitys verticillata, fossil Cerebropollenites from Aptian/ Albian strata (Austria, Mongolia) and Sciadopityspollenites from Campanian/Maastrichtian and Oligocene/Miocene strata (Siberia, Germany). Measurements and image comparisons show that the investigated fossil pollen taxa range from somewhat comparable to very similar to extant Sciadopitys verticillata, and that a previous affiliation of Cerebropollenites taxa with Tsuga cannot be corroborated. Additionally, it can be speculated that either the Rhaetian to Lower Cretaceous Cerebropollenites taxa are the pollen equivalent of the Eurasian Miroviaceae macrofossils that have unresolved relationships with Sciadopityaceae, or that they might belong to a basal group in the Sciadopityaceae, which is quite recognizable due to the similarity of the pollen morphology of Cerebropollenites thiergartii and Sciadopitys verticillata. However, until in situ pollen within cones attributed to the Miroviaceae are found, we will not know for sure.
\end{abstract}

Key words: Sciadopityaceae, pollen, Cretaceous, Neogene, Cerebropollenites, Sciadopityspollenites

Received: June 29, 2021 | Accepted: September 10, 2021 | Issued: December 24, 2021

\section{Introduction}

The extant umbrella pine (Sciadopitys verticillata SiEBold et ZuCC.) is the only member of the phylogenetically isolated Sciadopityaceae LuERss. (Farjon 2005, Eckenwalder 2009, Earle 2021), and is an evergreen conifer tree now only present in southern and western Japan, where it is restricted to parts of southern Honshu, Shikoku, and Kyushu (Farjon 2005, Earle 2021). Here it occurs on rocky slopes in mixed middle altitude cloud forests at 500-1,200m elevation (Farjon 2005, Eckenwalder 2009, Earle 2021). In contrast to its very restricted distribution today, its macrofossils are known from the northern hemisphere of Eurasia since the Upper Cretaceous from Japan (Saiki 1992, Uemura 1986), probably the Paleocene of Canada (Christophel 1973) and since the Eocene in Germany (Dolezych and Schneider 2006, Sadowski et al. 2016). There are even earlier occurrences affiliated to Sciadopityaceae all summarized in the family of Miroviaceae M.N.Bose et Manum, but the relationships of these fossils to Sciadopityaceae are not resolved (see below).

To reconstruct the fossil history of Sciadopityaceae, we focus here on fossil pollen genera associated with Sciadopityaceae, such as Sciadopityspollenites R.Potonié, and on the fossil pollen genus Cerebropollenites T.NiLsson, which has been compared, particularly C. macroverrucosus (Thierg.) Eberh.Schulz (synonyms of this species are also:
Pollenites macroverrucosus THIERG., Tsugaepollenites mesozoicus COUPER and Cerebropollenites mesozoicus (Couper) Tage Nilsson; see Schulz 1967: 603), with extant Tsuga canadensis CARRIÈRE (Couper 1958, Nilsson 1958). The genus Sciadopityspollenites is known from the Upper Cretaceous onwards (this paper and Takahashi 1997). After Potonié (1967: 153), the species Sciadopityspollenites serratus (R.Potonié et Venitz) RaAtz ex R.Potonié has been affiliated with extant Sciadopitys verticillata, and should be used only when the pollen in question is undoubtedly Sciadopitys Siebold et Zucc. This has been corroborated by investigating pollen wall ultrastructures of fossil Sciadopityspollenites and extant Sciadopitys taxa (Surova and Kvavadze 1988). The Upper Cretaceous record is also known to consist of macrofossils of Sciadopitys (Ohsawa et al. 1991, Saiki 1992; both ovulate cones), but macrofossils and pollen were much more common during the Neogene (e.g., Manum 1962, Krutzsch 1971, Boulter and Kvaček 1989, Schneider 1992, Hofmann et al. 2002, Stuchlik et al. 2002, Dolezych and Schneider 2006, Grimsson and Zetter 2011). The pollen genus Cerebropollenites occurs from the Lower Jurassic (Hettangian) to Lower Cretaceous in the northern hemisphere (e.g., Fisher and Dunay 1981, Visscher and Brugman 1981, Herngreen et al. 1996, Larsson 2009). In later papers, Cerebropollenites pollen were analysed using TEM (e.g., Batten and Dutta 1997, 
Shang and Zavada 2003), and these authors also suggested affinities with Tsuga CARriÈRE, or at least an old lineage leading to or an ancestral group of Tsuga, despite the fact that Tsuga-like macrofossils are known only from the Upper Cretaceous strata onwards (e.g., Kirchheimer 1934, Florin 1963, Ferguson 1967, LePage 2003). However, not everybody was convinced by this botanical affiliation: Klaus (1987: 260) describes Tsugaepollenites mesozoicus Couper ( $\equiv$ Cerebropollenites mesozoicus $=C$. macroverrucosus $)$ as a pollen with Sciadopitys-habit, and other scientists instead of using the pollen genus Cerebropollenites preferred Sciadopityspollenites such as: "S. macroverrucosus" and "S. mesozoicus" (Waksmundzka 1981, Ilyina 1985, Ichinnorov 2003, Kuzmichev et al. 2018), thus increasing the number of species in Sciadopityspollenites. To clear up these misunderstandings, this paper represents various Cerebropollenites and Sciadopityspollenites pollen grains analysed with LM and SEM from various localities and ages, and compares them with extant pollen of Sciadopitys verticillata to show that both the fossil genera are related.

\section{Material and methods}

The fossil pollen grains come from four localities in total, two of Lower Cretaceous, one Upper Cretaceous, and one Oligocene/Miocene ages. The extant pollen come from Japan, collected by LJS from the Daija-Gura cliff edge of the Mt. Odaigahara plateau (altitude 1,500-1,560 m), Nara Perfecture, Central Japan, in 2012.

Locality 1. The Aptian to Albian near coastal sediments from Austria (Rehbreingraben Formation "Gaultflysch"; Egger and Coric 2017). The stratigraphic age of the Austrian locality, which is situated near St. Pölten (Lower Austria), has been constrained by dinoflagellate cysts (see Egger and Coric 2017: 49-51).

Locality 2. The Aptian to Albian coal-bearing strata from Mongolia (Khovil-open pit mine) in the KhovilTugrug subbasin (Choir-Nyalga basin, SE of Ulaanbaatar, central Mongolia), for which the stratigraphic range has been determined by the presence of various Pilosisporites notensis COOKSON et M.E.DetTMAnN, Osmundacidites wellmanii COUPER, Aequitriradites spinulosus (COOKSON et M.E.Dettman) Cookson et M.E.Dettman, Taurocusporites reduncus (BoLKH.) STOVER, Leptolepidites verrucatus COUPER, Cicatricosisporites australiensis R.Potonié, Cyathidites australis COUPER, Pinuspollenites aralicus Bolkh., Alisporites sp. Cycadopites sp., Araucariadites australis CoOKson, Classopollis classoides Pflug etc. (Hofmann et al. in prep.).

Both Aptian/Albian localities contain palynological assemblages dominated by bryophytes, fern spores and pollen of Pinaceae, Cupressaceae and Ginkgoaceae.

Locality 3. The Campanian/Maastrichtian strata of the Timerdayakh Formation come from sedimentological profiles of riverbank outcrops along the Tyung River in the Vilui basin (west Siberia, Russia). Most of the samples yielded various stratigraphically valuable species of Aquilapollenites Rouse emend. by Srivastava and Rouse (1970), Manicorpus N.Mchedl. and Azonia SAmoJlovitch pollen. The investigated material comprises very finegrained to fine-grained floodplain, palaeosol, peat, lake and mud clast/drape sediments (Hofmann and Zetter 2007, 2010, Spicer et al. 2008).

Locality 4. The Oligocene/Miocene sedimentary succession of the Bayerhof-Maar (Bavaria, Germany) starts with a volcanic breccia, and is then filled with lake sediments that are terminated by a swampy to peaty phase (Rohrmüller 2003). The Maar is part of a Neogene volcanic zone in the still tectonically active area between the Eger rift and the Franconian line at the margin of the Bohemian mountains, and the sediments have K/Ar-age of 23.3 and 21.7 myr (Rohrmüller and Horn 2003). The microflora represents a peculiar mixture of Oligocene and Miocene elements (Sachse and Hofmann 2020).

The sedimentary rock samples were washed, dried and milled with a mortar and pestle. The resulting powder was treated with $\mathrm{HCl}, \mathrm{HF}$ and subsequent acetolysis to reduce silicate, carbonates, organic material such as wood and other palynodebris, and to darken the colour of the palynomorph walls. The remaining palynomorph extract was mixed with glycerine and stored in small glass vials. For investigation, a drop of extract was smeared onto a glass slide and evenly spread to search for pollen to be investigated. The investigated pollen grains then were transferred with a micro-manipulator (fine hair glued to a preparation needle) to a clean drop of glycerine on another slide and photographed. Then these pollen grains were again transferred with a micro-manipulator onto a SEM stub, washed with alcohol and then sputtered with gold. SEM investigation was done with a FEI Inspect S 5001. Pollen sacs from a small male pollen cone of extant Sciadopitys verticillata were soaked in a drop of acetolysis mixture on a glass slide and manipulated with a needle to release the pollen from the sacs. The sacs in the acetolyses mixture were repeatedly heated up for a few seconds over a candle flame to colour the pollen wall and drive out the cell contents. The pollen was then fished out with a micro-manipulator (hair mounted on a needle) and transferred to a clean drop of glycerol for LM photography, together with a micrometer (Nikon). After photography, the pollen was moved with a micro-manipulator to SEM stubs, like the fossil pollen. The stubs are stored under inventory numbers IPUW $383010 \mathrm{a}-\mathrm{j}, 7840$ 20a-f, 7840_30a-f at the Institute of Palaeontology, University Vienna (IPUW).

\section{Systematic palaeobotany}

Measurements of extant and fossil pollen of Sciadopityaceae and some Tsuga species and measurements from the literature (Macko 1957, Couper 1958, Schulz 1967, Stuchlik et al. 2002) are summarized in Table 1, and show that the size of Sciadopitys verticillata pollen corresponds with sizes of all fossil Cerebropollenites spp. and Sciadopityspollenites pollen, and are considerably smaller than extant and fossil Tsuga pollen (Kirchheimer 1934, Ueno 1951, Ho and Sziklai 1972, Grimsson and Zetter 2011, Sachse and Hofmann 2020, Hofmann unpublished data). 
Family Sciadopityaceae LuERSS., 1877

Genus Sciadopitys Siebold et Zucc., 1842

Sciadopitys verticillata Siebold et ZuCC., 1842

Text-fig. 1a-i

Description. Monad pollen of spheroidal to suboblate shape, elliptical to circular in polar view and elliptical in equatorial view; equatorial diameter 41.7 to $53.3 \mu \mathrm{m}(\mathrm{LM}, \mathrm{N}=11)$ and 24.4 to $37.1 \mu \mathrm{m}(\mathrm{SEM}, \mathrm{N}=5)$; polar diameter 35.5 to $43.3 \mu \mathrm{m}(\mathrm{LM}, \mathrm{N}=3)$ and 23.8 to $24.6 \mu \mathrm{m}(\mathrm{SEM}, \mathrm{N}=2)$; wall thickness in general using LM ranges from 2.3 to $3.3 \mu \mathrm{m}(\mathrm{N}=1)$, using SEM $1.7 \mu \mathrm{m}(\mathrm{N}=1$; nexine ca. $0.6 \mu \mathrm{m}$ and sexine ca. $1.1 \mu \mathrm{m})$; wall thickness at the leptoma was not measurable under LM and once under SEM: nexine $0.4 \mu \mathrm{m}$; sexine 0.3 to $0.7 \mu \mathrm{m}$ (if present); sculpturing verrucate and occasionally slightly rugulate, perforate to foveolate with evenly spaced supratectal echini, rugulae and verrucae are not the result of a folding sexine; leptoma area either naked or unevenly covered by angular, partly echinate micro-verrucae.

R e m a r ks. The verrucae and rugulae are the smallest of here-investigated pollen.

\section{Genus Cerebropollenites Tage Nilsson, 1958}

\section{Cerebropollenites thiergartii EBERH.SCHULz, 1967}

Text-fig. 2a-c

O c c u r r e n c e . Locality 1, St. Pölten, Austria.

Description. Monad pollen of subspheroid to suboblate shape, elliptical in equatorial view; equatorial diameter ca. $55.5 \mu \mathrm{m}$ (LM) to $48.9 \mu \mathrm{m}$ (SEM); polar diameter ca. $40 \mu \mathrm{m}(\mathrm{LM})$ to $37.6 \mu \mathrm{m}$ (SEM, $\mathrm{N}=1$ ); wall thickness 2.5 to $3.1 \mu \mathrm{m}$; nexine thinner than sexine; sculpturing verrucate

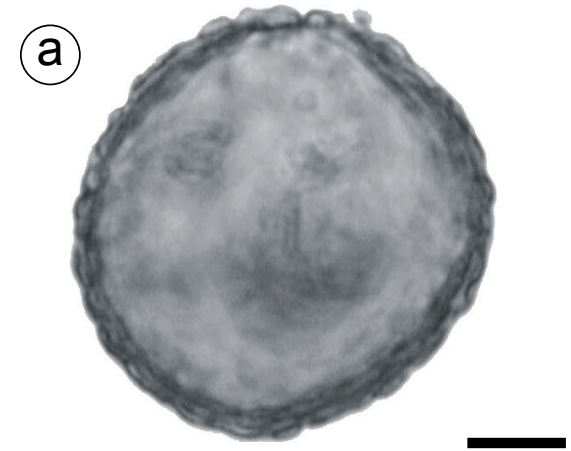

(b)

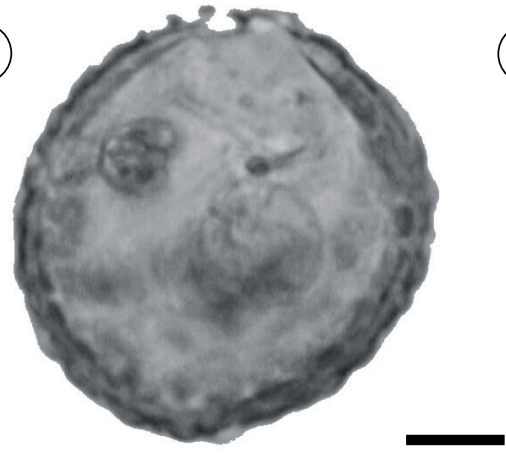

(C)
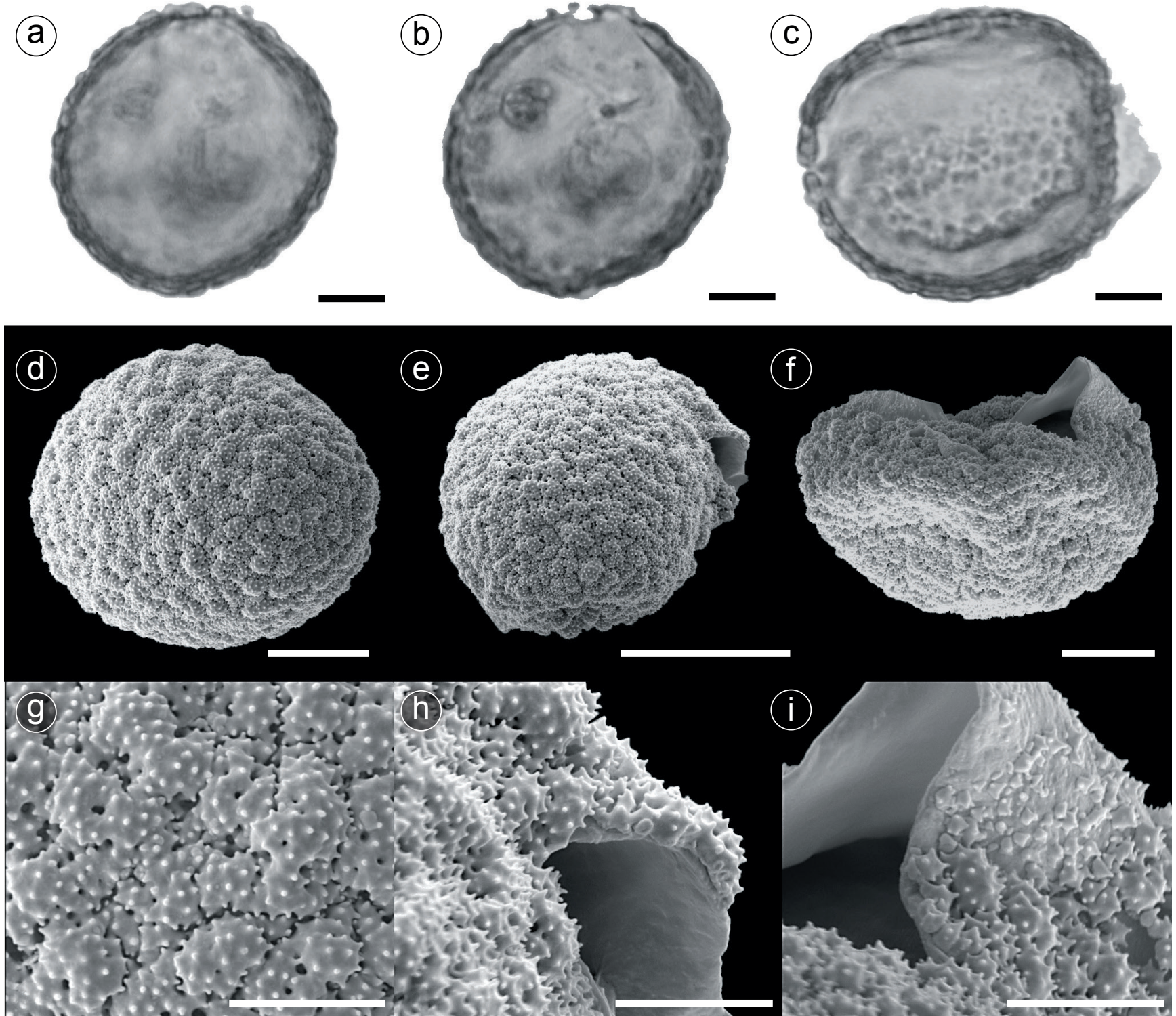

Text-fig. 1. Extant Sciadopitys verticillata pollen. a-c: LM images (scale bars $10 \mu \mathrm{m}$ ), a - polar view, b - equatorial view, c equatorial view with well visible thinning of proximal leptoma; d-e: SEM overview images (scale bar $10 \mu \mathrm{m}$ ), $\mathrm{d}-\mathrm{distal}$ polar view, e - oblique equatorial view; $\mathbf{f}$ - equatorial view with leptoma at top; g-i: SEM detailed images (scale bars $2 \mu \mathrm{m}$ ), $\mathrm{g}$ - detail of verrucate, echinate, perforate sexine of distal pol, $\mathbf{h}$ - wall break displaying thin nexine and verrucate, echinate sexine, $i$ - ripped open leptoma displaying transition from verrucate sculpturing to nearly psilate state. 

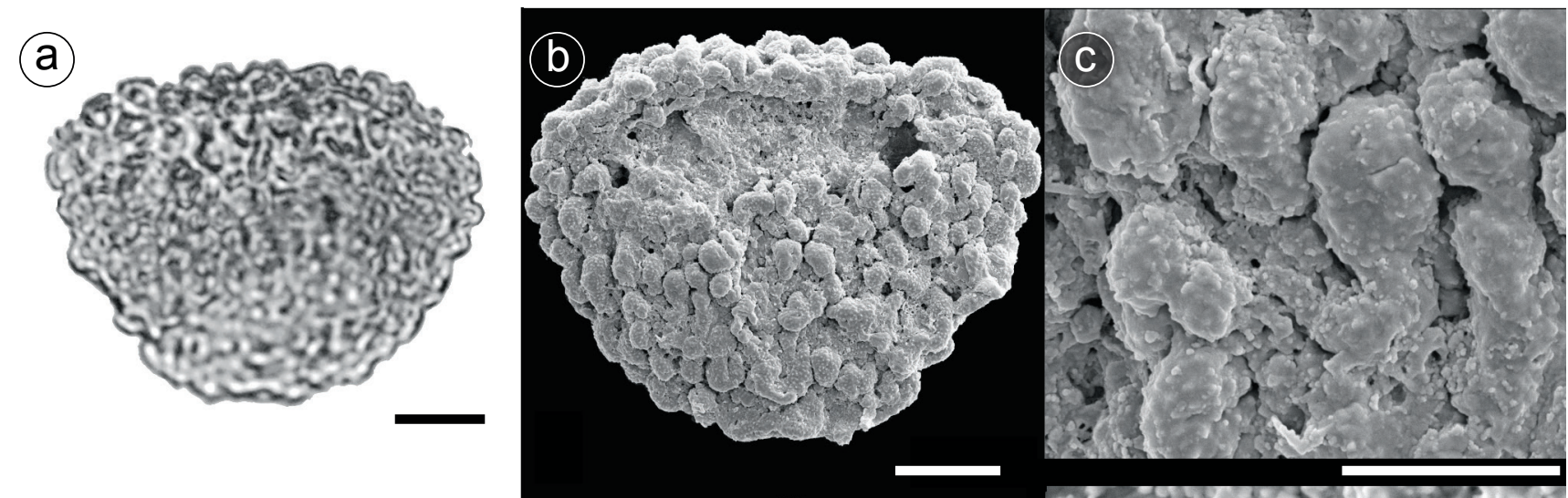

(d)
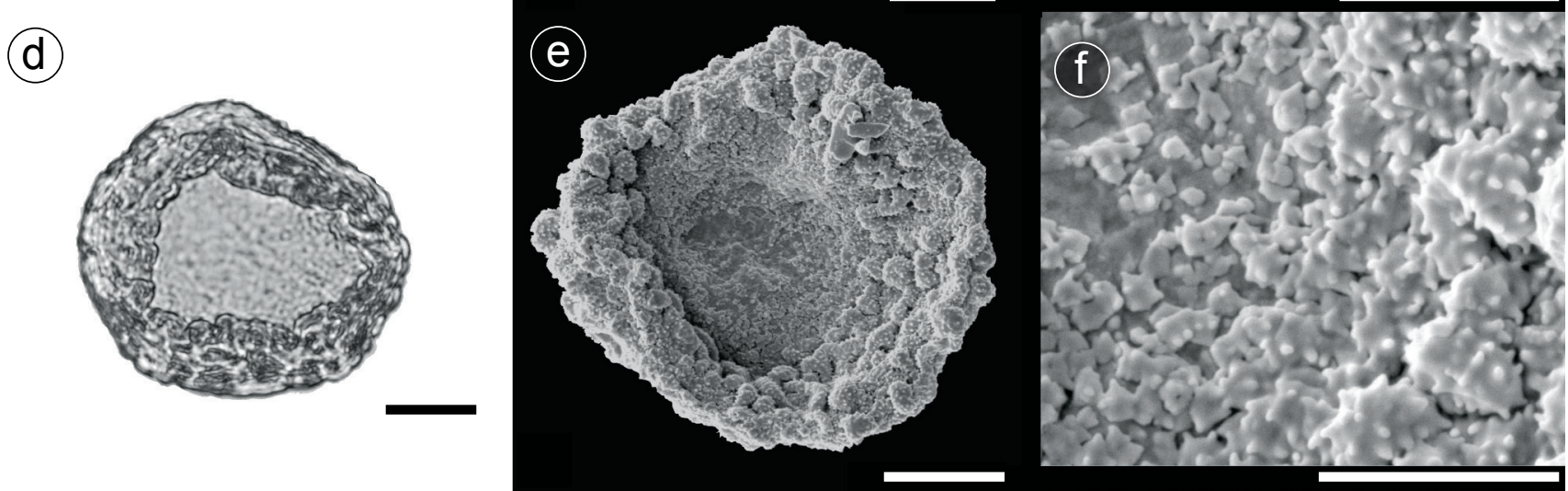

(9)
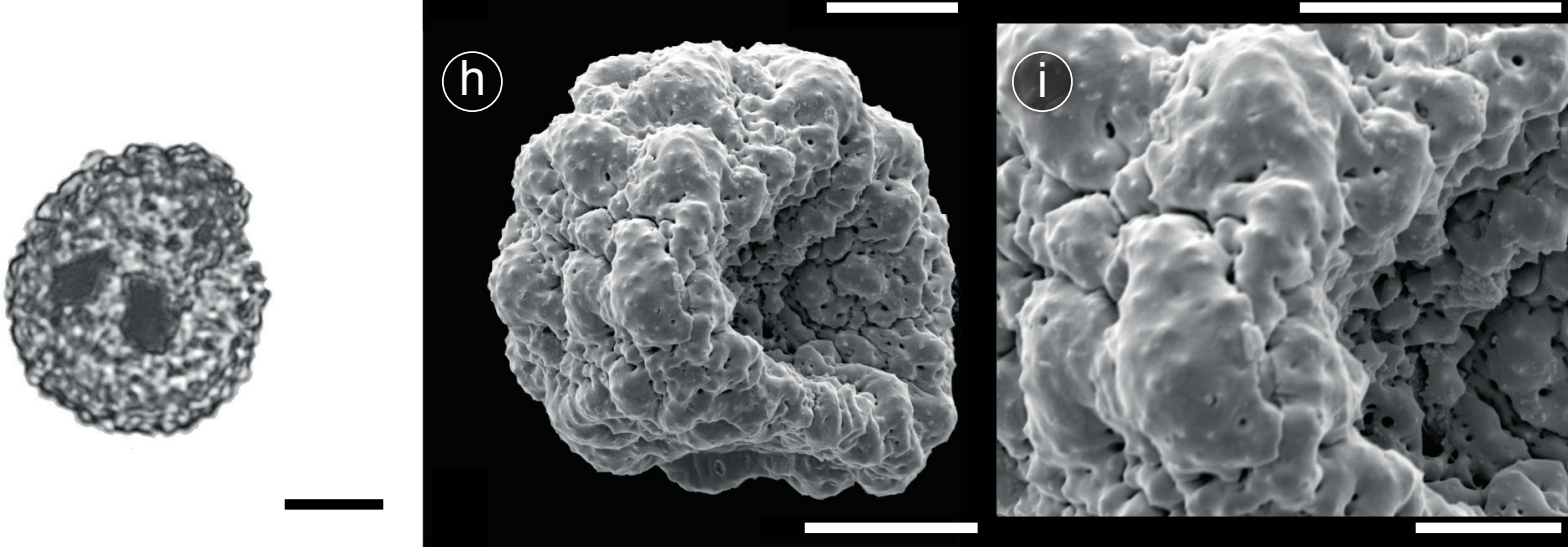

Text-fig. 2. Aptian to Albian Cerebropollenites taxa, all scale bars in LM and SEM overview images $10 \mu \mathrm{m}$, scale bars in SEM detailed images $2 \mu \mathrm{m}$. a-c: Cerebropollenites thiergartii from St. Pölten (Austria), a - LM image, equatorial view, b-SEM equatorial overview with visible, less sculptured leptoma, $\mathrm{c}$ - detail of echinate verrucae; d-f: Cerebropollenites thiergartii from Khovil basin (Mongolia), d - LM image polar view with well visible thin-walled leptoma, e-SEM of proximal polar view with faintly sculptures leptoma, f - SEM detailed view of transition from leptoma to normal sexine sculpturing; $\mathrm{g}-\mathrm{i}$ : Cerebropollenites macroverrucosus from Khovil basin (Mongolia), $\mathrm{g}$ - LM image of oblique equatorial view, $\mathrm{h}$ - SEM of oblique equatorial view with concave leptoma, $\mathrm{i}$ - SEM detail of the rugulate to verrucate sexine and smaller sculpturing in leptoma area.

to occasionally rugulate and perforate covered with evenly spaced supratectal echini; leptoma area either naked or unevenly covered by angular, partly echinate micro-verrucae.

\section{Cerebropollenites thiergartii ЕвERH.SChULZ, 1967}

Text-fig. $2 \mathrm{~d}-\mathrm{f}$

Occurrence. Locality 2, Khovil opencast mine, Mongolia.

Description. Monad of subspheroidal shape, circular to elliptical pollen grain in polar view, and elliptical in equatorial view; equatorial axes 42.4-48.7 $\mu \mathrm{m}$ (LM) and 33.1 to $37.4 \mu \mathrm{m}$ (SEM), polar axis ca. $24.4 \mu \mathrm{m}$ (SEM, $\mathrm{N}=3$ ); wall thickness ca. 2.2 to $2.8 \mu \mathrm{m}$, probably thinning towards the leptoma (thinning well visible on LM image); sculpturing verrucate to occasionally rugulate, perforate, with evenly distributed supratectal echini; leptoma partly covered with echinate micro verrucae.

R e m a r k s. In two C. thiergartii specimens the verrucae are considerably smaller than in C. macroverrucosus (see below), and very well comparable to the ones in Sciadopityspollenites serratus and extant Sciadopitys verticillata.

\section{Cerebropollenites macroverrucosus (THIERG.)}

EBERH.SCHULZ, 1967

Text-fig. $2 \mathrm{~g}-\mathrm{i}$

Occurrence. Locality 2, Khovil opencast mine, Mongolia. 
D e s c ription. Monad of spheroidal shape; circular to subcircular in polar and equatorial view; equatorial axes $35.5 \mu \mathrm{m}(\mathrm{LM})$ and 26.6 to $31 \mu \mathrm{m}(\mathrm{SEM}, \mathrm{N}=1)$; equatorial diameter ca. 31.1 (LM) and $18.3 \mu \mathrm{m}$; wall thickness ca. 1.8 to $2.7 \mu \mathrm{m}$, probably thinning towards the leptoma; sculpturing rugulate to verrucate, unevenly and faintly perforate, with loosely arranged supratectal echini; leptoma covered with smaller echinate verrucae.

Remarks. Here the rugulae and verrucae are the largest in the investigated pollen.

\section{Sciadopityspollenites R.Potonié, 1958}

cf. Sciadopityspollenites serratus (R.PotoniÉ et VENITz) R.Potonié, 1958

Text-fig. 3a-f
O c c u r r e n c e. Locality 3, Vilui Basin opencast mine, Russia.

D e s c r i p t i o n. Monad pollen of spheroidal to oblate shape, elliptical to circular in polar view and elliptical in equatorial view; equatorial diameter ca. 45.5 to $53.3 \mu \mathrm{m}$ (LM) and 26.4 to $35.7 \mu \mathrm{m}(\mathrm{SEM}, \mathrm{N}=2$ ); the polar diameter ca. 36.6 to $37.7 \mu \mathrm{m}$ (LM) and 27.2 to $29 \mu \mathrm{m}$ (SEM); wall thickness ca. 2.4 to $2.8 \mu \mathrm{m}$, nexine thinner than sexine; wall thickness at leptoma was not measurable under LM, but looks thinner; sculpturing verrucate, perforate covered densely with evenly spaced supratectal echini; leptoma sulcus shaped and much less ornamented.

$\mathrm{R} \mathrm{e} \mathrm{m} \mathrm{a} \mathrm{r} \mathrm{k} \mathrm{s.} \mathrm{These} \mathrm{specimens} \mathrm{are} \mathrm{very} \mathrm{comparable} \mathrm{with}$ extant pollen, but have smaller and fewer perforations than the Oligocene to Miocene Sciadopityspollenites serratus described below. (a)

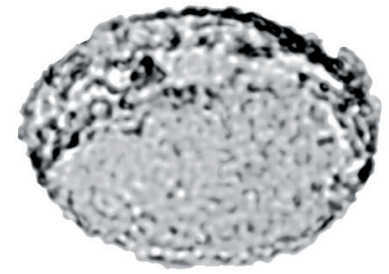

(d)
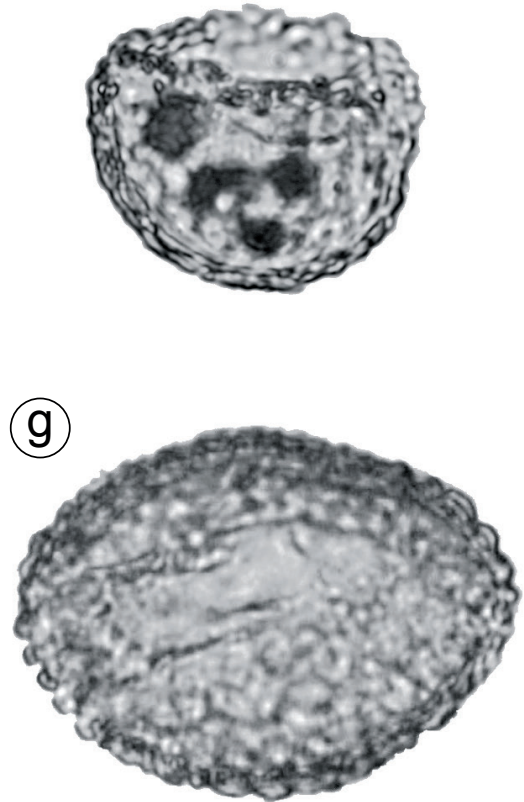
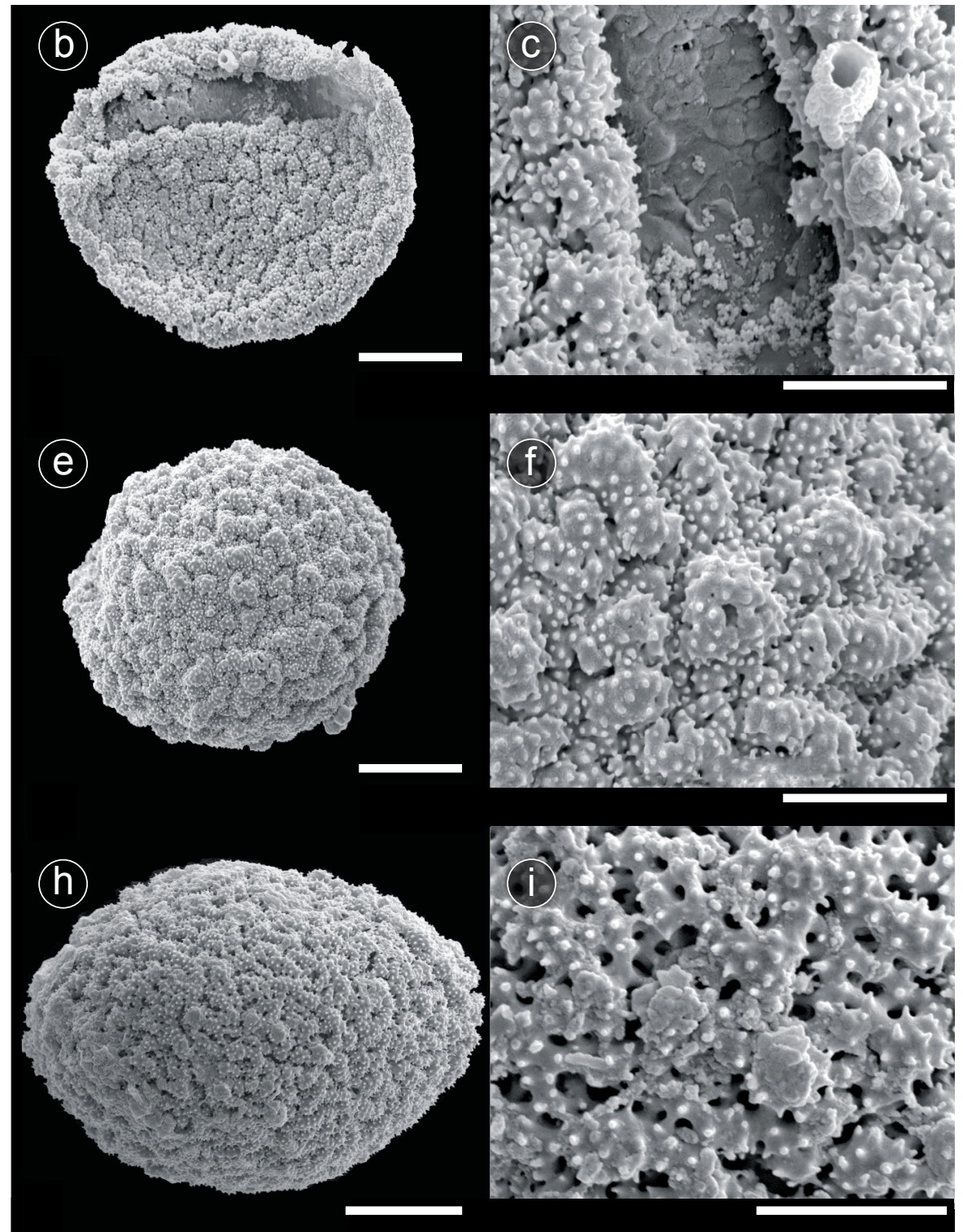

Text-fig. 3. Upper Cretaceous to Oligocene/Miocene Sciadopityspollenites taxa, all scale bars in LM and SEM overview images $10 \mu \mathrm{m}$, scale bars in SEM detailed images $2 \mu \mathrm{m}$. a-f: cf. Sciadopityspollenites serratus from Vilui basin (Siberia), a - LM image, equatorial view, b - SEM equatorial overview with leptoma, $c$ - detail SEM of leptoma? and echinate verrucae, $d$ - LM image equatorial view, e - SEM of distal polar view, $f$ - SEM detailed view of verrucate, echinate perforate sexine sculpturing; $g$-i: Sciadopityspollenites serratus from Bayerhof Maar (Germany), g - LM image of proximal polar side, h - SEM overview of distal polar side, i - SEM detail of verrucate, echinate, perforate sculpturing. 


\section{Sciadopityspollenites serratus (R.PotoniÉ et VenITz) R.Potonié, 1958 \\ Text-fig. $3 \mathrm{~g}-\mathrm{i}$}

O c c u r re n c e. Locality 4, Bayerhof Maar, Germany.

Description. Monad pollen of subspheroidal to oblate shape, elliptical to circular in polar view, elliptical in equatorial view; equatorial diameter ca. 36.5-48.8 $\mu \mathrm{m}$ (LM) and 38.6 to $50.5 \mu \mathrm{m}(\mathrm{SEM}, \mathrm{N}=1)$; wall thickness ca. 1.9 to $2.2 \mu \mathrm{m}$; nexine thinner than sexine; wall thickness at leptoma was not measurable under LM but looks thinner; sculpturing verrucate to rugulate and faintly perforate covered with evenly spaced supratectal echini; leptoma sulcus shaped and much less ornamented (visible under LM).

R e m a r k s. This pollen grain has also been displayed in Sachse and Hofmann (2020), and is more perforated than the extant specimens.

\section{Discussion}

There are considerable differences in pollen sizes, depending whether one measures the pollen in glycerol or a comparable mounting medium under LM, or in a more desiccated state after washing with alcohol under SEM; the SEM measurements are always smaller (Tab. 1 and descriptions). In the older literature (e.g., Macko 1957, Couper 1958, Schulz 1967), the sizes are the result of measurements under LM, and the maximal sizes are considerable larger than the SEM sizes (compare data of Grimsson and Zetter 2011: 203). Additionally, the longer the time span whilst acetolyzing extant pollen material, the more the size decreases, and even the shape of the pollen can change. It is suggested that the individual fossilization processes (depth, temperature, pressure) have an influence on the varying sizes of fossil pollen in different localities: for example, the pollen of Cerebropollenites macroverrucosus and $C$. thiergartii from the opencast Khovil basin coal (Mongolia) are relatively smaller than the ones described by Schulz (1967) from Central Europe. The same is true for $C$. thiergartii from St. Pölten (Austria). Generally, when comparing pollen sizes of extant species with fossil Sciadopityaceae, the fossil ones are somewhat smaller, and overall, the pollen of Sciadopityaceae are smaller than extant and fossil Tsuga species (Tab. 1). This also can be said for the size of the leptoma of Sciadopityaceae and Tsuga on the proximal pole (Tab. 1).

All pollen investigated are characterised by more-orless regularly distributed very small supratectal echini, these echini are quite loosely arranged on Cerebropollenites macroverrucosus, but densely arranged on the rest of the extant and fossil investigated pollen grains. In contrast, only one species of Tsuga ( $T$. heterophylla SARG.) is somewhat echinate (see Ho and Sziklai 1972: figs. 23, 24; Sachse and Hofmann 2020: pl. 2, figs. 5, 6 of fossil Tsuga heterophyllatype), but the echini are much larger and longer than the echini of Sciadopityaceae. The same is true for the presence of perforations of the sexine in extant (well visible) and fossil Sciadopityaceae: they are quite conspicuous (nearly foveolate in the Oligocene/Miocene Sciadopityspollenites serratus), fairly visible on Cerebropollenites thiergartii, and not so well observable on Cerebropollenites macroverrucosus. Tsuga, on the other hand, has no perforations in the sexine.

The TEM investigation of pollen walls of extant Sciadopitys verticilliata by Kurmann (1992: fig. 2C) and Uehara and Saiki (2011: figs 12-18) show that the sculpturing of the sexine is not the result of an undulating sexine, as suggested by Batten and Dutta (1997: 35, 37), and to some degree by Shang and Zavada (2003), but a result of a continuous size increase of ectexine granules that at the end can fuse to produce a relatively unstructured layer (Uehara and Saiki 2011: 181-182). The undulating or folding sexine is a feature that can be clearly observed in extant Tsuga canadensis (Kurmann 1992: TEM section fig. 1d). However, in Shang and Zavada (2003: TEM sections in figs 8-11), an occasional undulating exine can be observed.

Besides the pollen record, we want to also discuss macrofossils assigned to the Sciadopityaceae, to reconstruct the biogeographical history of this family. The most common fossils are of the cladodes, although cones, seeds and wood are also preserved. In extant Sciadopitys these cladodes, sometimes termed "double-needles" (e.g., Eckenwalder 2009), are the photosynthetic organs, as the leaves are very reduced. They are characterised as long and thin needle-like structures with an emarginate tip and a glabrous adaxial groove, and a deep central abaxial papillate groove (Florin 1931, Eckenwalder 2009, Dörken and Stützel 2011). The stomata are within the abaxial groove, but obscured by the papillae (Farjon 2005). Additionally, there are the two vascular bundles running on either side of the median groove (Dörken and Stützel 2011).

The earliest Sciadopitys-like macrofossils consisting of cones and cladodes are Upper Cretaceous-aged remains from Japan (Ogura 1932, Tsukada 1963, Ohsawa et al. 1991, Saiki 1992). During the Cenozoic, these fossils (cladodes assigned to Sciadopitys tertiaria MENZEL, cones and wood fragments assigned to Sciadopityoxylon wettsteinii JURASKY) occur more frequently in Europe from the Eocene - Pliocene (Menzel 1913, Florin 1922, Jurasky 1928, Gothan 1936, Thiergart 1949, Weyland et al. 1967, Schneider 1992, 2004, 2008, Mai 1995, 1999, 2000, 2004, Figueiral et al. 1999, Philippe et al. 2002, Dolezych 2005, Dolezych and Schneider 2006, Manchester et al. 2009), with cladodes assignable to Sciadopitys occurring in Eocene Baltic amber (Sadowski et al. 2016). There are suggestions that Sciadopitys was a source plant for this amber deposit, based on chemical analyses (Wolfe et al. 2009). The incompletely preserved Sciadopitophyllum canadense CHRISTOPHEL is not thought to be closely related as the emarginate leaf tips and cuticular features were not preserved (Christophel 1973)

Older (Lower Jurassic to Lower Cretaceous) fossil conifer needles with a deep abaxial papillate groove had been thought to be Sciadopitys-like, and were described as Sciadopitytes Göpr. et Menge in Halle (1915). This was transferred to Sciadopityoides SvesHnIK., which was then subsequently split in to Mirovia Reyman. emend. by Bose and Manum (1991), Oswaldheeria M.N.Bose et Manum, Holkopitys M.N.Bose et MAnum and Sciadopityoides Sveshnik. emend. by Bose et Manum (1991). Species assigned to Oswaldheeria were then transferred back to Mirovia following reinvestigation of the type material (Nosova and Wcisło-Luraniec 2007). Now these genera 
Table 1. Measurements of extant and fossil Sciadopityaceae and Tsuga pollen grains, and some data from the literature. Abbreviations: verr $=$ verrucate, rugul $=$ rugulate, micr-verr $=$ micro-verrucate, suprat. $=$ supratectal, Rhaet $=$ Rhaetian, Hett $=$ Hettangian, Juras $=$ Jurassic, Cretac $=$ Cretaceous, Apt $=$ Aptian, Alb $=$ Albian, Camp $=$ Campanian, Maast $=$ Maastrichtian, Olig $=$ Oligocene, Mioc $=$ Miocene. Symbols: * = questionable, because the ectexine sculpture under SEM of this taxon resembles more Cupressaceae than Sciadopityaceae.

\begin{tabular}{|c|c|c|c|c|c|c|c|}
\hline taxon & age; place & $\begin{array}{c}\text { equatorial axe } \\
\text { in } \mu \mathrm{m} \mathrm{LM} / \mathrm{SEM}\end{array}$ & $\begin{array}{c}\text { polar axe } \\
\text { in } \mu \mathrm{m} \mathrm{LM} \mathrm{/} \mathrm{SEM} \\
\end{array}$ & \begin{tabular}{|c|} 
leptoma size \\
in $\mu \mathrm{m} \mathrm{LM} \mathrm{/} \mathrm{SEM}$
\end{tabular} & \begin{tabular}{|c|} 
sculpture \\
SEM
\end{tabular} & \begin{tabular}{|c|} 
suprat. \\
echini
\end{tabular} & reference \\
\hline Sciadopitys verticilliata & extant; Japan & $\begin{array}{c}41.7-53.3 / \\
24.4-37.1 \\
\end{array}$ & \begin{tabular}{|c|}
$35.5-43.3 /$ \\
$23.8-24.6$ \\
\end{tabular} & \begin{tabular}{|c|}
$26.6-40 /$ \\
$25.2-25.6$ \\
\end{tabular} & verr-rugul & dense & this paper \\
\hline Sciadopitys verticilliata & extant & $38-45 /$ & - & $34-36 /$ & verr & - & Stuchlik et al. 2002 \\
\hline $\begin{array}{l}\text { Tsugaepollenites } \\
\text { mesozoicus }\end{array}$ & $\begin{array}{c}\text { Juras/Cretac; } \\
\text { Britain }\end{array}$ & $45(65) 88 /$ & - & - & rugul-verr & $?$ & Couper 1958 \\
\hline $\begin{array}{l}\text { Cerebropollenites } \\
\text { macroverrucosus }\end{array}$ & $\begin{array}{l}\text { Rhaet/Hett; } \\
\text { Germany }\end{array}$ & $? 82 /$ & $? 42 /$ & $16-20 /$ & rugul-verr & $?$ & Schulz 1967 \\
\hline $\begin{array}{l}\text { Cerebropollenites } \\
\text { thiergartii }\end{array}$ & $\begin{array}{l}\text { Rhaet/Hett; } \\
\text { Germany }\end{array}$ & $40(56) 80 /$ & - & $<36 /$ & verr & $?$ & Schulz 1967 \\
\hline C. macroverrucosus & Abt/Alb; Mongolia & 35.5 / 26.6-31 & $31.1 / 18.3$ & $15.5 / 10$ & rugul-verr & loose & this paper \\
\hline C. thiergartii & Abt/Alb; Austria & $55.5 / 48.9$ & $40 / 37.6$ & $36.7 / 27.4$ & verr & dense & this paper \\
\hline C. thiergartii & Abt/Alb; Mongolia & $\begin{array}{l}42.4-48.7 / \\
33.1-37.4 \\
\end{array}$ & / 24.4 & $34.4 / 20$ & verr & dense & this paper \\
\hline $\begin{array}{l}\text { Sciadopityspollenites } \\
\text { serratus }\end{array}$ & $\begin{array}{l}\text { Camp/Maast; } \\
\text { Siberia, Russia }\end{array}$ & $\begin{array}{c}45.5-53.3 / \\
26.4-35.7 \\
\end{array}$ & $\begin{array}{c}36.3-37.8 / \\
27.2-29 \\
\end{array}$ & $37-44 / 28$ & verr & dense & this paper \\
\hline S. serratus & $\begin{array}{l}\text { Oligo/Mioc; } \\
\text { Germany }\end{array}$ & $\begin{array}{l}36.6-48.8 / \\
38.6-50.5\end{array}$ & - & $35.5 /$ & verr & dense & this paper \\
\hline S. miniverrucatus* & $\begin{array}{l}\text { mid Miocene; } \\
\text { Poland }\end{array}$ & $33-46 / 33.8-36.6$ & - & $22.7-29.4$ & micr-verr & - & Stuchlik et al. 2002 \\
\hline S. quintus & $\begin{array}{l}\text { mid Miocene; } \\
\text { Poland }\end{array}$ & $34-41 / 31.4-41.4$ & - & $23-29 /$ & - & dense & Stuchlik et al. 2002 \\
\hline S. tuberculatus & Miocene; Poland & $30-60 / 26.1-37.8$ & - & $26-40 /$ & rugul-verr & dense & Stuchlik et al. 2002 \\
\hline S. tubulus* & $\begin{array}{l}\text { mid Miocene; } \\
\text { Poland }\end{array}$ & $36-51 / 24.3-29.1$ & - & $26-28 /$ & micr-verr & - & Stuchlik et al. 2002 \\
\hline S. varius & $\begin{array}{l}\text { mid Miocene; } \\
\text { Poland }\end{array}$ & $35-55 /$ & - & $36-38 /$ & verr & - & Stuchlik et al. 2002 \\
\hline S. verticilliatiformis* & Mioc/Plio; Poland & $\begin{array}{l}32.8-41 / \\
25.3-29.7\end{array}$ & - & - & micr-verr & - & Stuchlik et al. 2002 \\
\hline Sciadopityspollenites sp. & $\begin{array}{l}\text { mid Miocene; } \\
\text { Poland } \\
\end{array}$ & $38-56 /$ & - & - & verr & - & Stuchlik et al. 2002 \\
\hline $\begin{array}{l}\text { "Sciadopitys verticilliata" } \\
\text { (fossil) }\end{array}$ & Miocene; Poland & $48-62 /$ & $35.6-46 /$ & - & verr & $?$ & Macko 1957 \\
\hline Sciadopitys sp. & Miocene; Austria & $38-45 / 35-40$ & $31-34 /$ & - & verr & dense & \begin{tabular}{|l|} 
Grimsson and Zetter \\
2011 \\
\end{tabular} \\
\hline Tsuga heterophylla & $\begin{array}{c}\text { extant; Brit. } \\
\text { Columbia, Canada }\end{array}$ & $73.1 /$ & $59 /$ & - & - & - & Ho and Sziklai 1972 \\
\hline Tsuga mertinsiana & $\begin{array}{c}\text { extant; Vancouver, } \\
\text { Canada } \\
\end{array}$ & $65.1 /$ & $61.9 /$ & - & - & - & Ho and Sziklai 1972 \\
\hline Tsuga spp. & extant; Japan & $>55$ & - & - & - & - & Ueno 1957 \\
\hline Tsuga sp. 1 & Miocene; Austria & $75-80 / 70-75$ & $40-45 /$ & $\begin{array}{c}67.7-70.7 / \\
50-55.1\end{array}$ & - & - & $\begin{array}{l}\text { Grimsson and Zetter } \\
2011\end{array}$ \\
\hline Tsuga sp. 2 & Miocene; Austria & $70-80 / 65-75$ & $40-50 /$ & $60-65 / 52$ & - & - & \begin{tabular}{|l} 
Grimsson and Zetter \\
2011 \\
\end{tabular} \\
\hline Tsuga sp. 1 & Miocene; Austria & $100 / 86.4$ & $75 /$ & 821 & - & - & Hofmann unpublished \\
\hline Tsuga sp. 2 & Miocene; Austria & $60 / 39.2$ & - & $33.3 /$ & - & - & Hofmann unpublished \\
\hline Tsuga heterophylla-type & $\begin{array}{c}\text { Oligo/Mioc; } \\
\text { Germany }\end{array}$ & $86.6 / 66.5$ & - & $66.6 / 57.3$ & - & - & \begin{tabular}{|l|} 
Sachse and Hofmann \\
2020
\end{tabular} \\
\hline Tsuga spp. & Pliocene & $33.6-88.2 /$ & - & - & - & - & Kirchheimer 1934 \\
\hline
\end{tabular}

are placed in the Miroviaceae M.N.Bose et Manum, which are distinguished from Sciadopitys by the absence of an emarginate tip and two veins (Bose and Manum 1991, Manum et al. 2000). These taxa originate from circumArctic localities (Halle 1915, Florin 1922, Bose 1955, Gothan and Weyland 1973, Bose and Manum 1990, 1991), Poland (Reymanówna 1985, Nosova and Wcisło-Luraniec 2007), Germany (Manum et al. 2000), Spain (Gomez 2002) and Kazakhstan (Nosova and Kiritchkova 2008). The exact relationship of the Miroviaceae to Sciadopitys remains uncertain.

If we combine the new fossil and extant pollen data and that of the macrofossils, a few points arise: if the pollen from the Lower Cretaceous localities in Europe and Asia (e.g., Cerebropollenites macroverrucosus and C. thiergartii) have putative macrofossil equivalents in the Miroviaceae 
family (which still has uncertain relationships to the extant Sciadopityaceae), and the fact that particularly $C$. thiergartii is very similar to extant and fossil (e.g., Sciadopityspollenites serratus) pollen of Sciadopityaceae, one could speculate that the fossil Miroviaceae family is either an extinct lineage of sciadopityaceaous-like plants, or sits as a group at the base of an evolving lineage of the Sciadopityaceae that is represented today by the relict species Sciadopitys verticillata. However, no male Miroviaceae cones including pollen have been found yet to prove that this is true. On the other hand, Sciadopityspollenites taxa ( $S$. serratus, S. quintus, S. tuberculatus, S. varius) and all Paleocene to Neogene macrofossils can undoubtedly be assigned to Sciadopityaceae.

\section{Conclusions}

The verrucate to rugulate nature of the sexine plus the supratectal micro-echinate ornamentation present on all pollen investigated here strongly indicate that they are related to Sciadopityaceae. Also, the smaller sizes of the pollen grains and the irregular shapes of the verrucae and rugulae might decrease and vary through the time of observation (Aptian through present), but we suggest that there is a clear evolutionary line leading from Cerebropollenites via Sciadopityspollenites to Sciadopitys verticillata, rather than to Tsuga, as proposed by some previous authors. However, because of the similarity of pollen of Cerebropollenites thiergartii with fossil Sciadopityspollenites taxa and Sciadopitys verticilliata, it can be only speculated whether the fossil pollen taxon Cerebropollenites is the pollen equivalent to the Miroviaceae family, and so represents an extinct lineage of "Sciadopitys"-like plants, or if this family represents a basal part of the Sciadopitys lineage, which is well documented from the Upper Cretaceous onwards in Eurasia.

\section{Acknowledgements}

N. O. thanks the OEAD for financing her stay at Vienna University during 2016. This paper is in honour of Z. Kvaček. We will always remember his kindness to everybody who was interested in plants, and his immense knowledge; he truly was one of the last great palaeobotanists.

\section{References}

Batten, D. J., Dutta, R. J. (1997): Ultrastructure of exine of gymnospermous pollen grains from the Jurassic and basal Cretaceous deposits in Northwest Europe and implications for botanical relationships. - Review of Palaeobotany and Palynology, 99: 25-54. https://doi.org/10.1016/S0034-6667(97)00036-5

Bose, M. N. (1955): Sciadopitytes variabilis n. sp. from the Arctic of Canada. - Norsk Geologisk Tidsskrift, 35: 53-67.

Bose, M. N., Manum, S. B. (1990): Mesozoic conifer leaves with Sciadopitys-like stomatal distribution. A reevaluation from fossils of Spitzbergen, Greenland and Baffin Island. - Norsk Polarinstitutt Skrifter, 192: 1-81.
Bose, M. N., Manum, S. B. (1991): Additions to the family Miroviaceae (Coniferae) from the Lower Cretaceous of West Greenland and Germany: Mirovia groenlandica n. sp., Tritaenia crassa (Seward) comb. nov., and Tritaenia linkii Mägdefrau et Rudolph emend. - Polar Research, 9: 9-20. https://doi.org/10.1111/j.1751-8369.1991.tb00399.x

Boulter, M. C., Kvaček, Z. (1989): The Palaeocene flora of the Isle of Mull. - Special Papers in Palaeontology, 42: $1-149$.

Christophel, D. C. (1973): Sciadopitophyllum canadense gen. et sp. nov.: a new conifer from western Alberta. American Journal of Botany, 60: 61-66. https://doi.org/10.1002/j.1537-2197.1973.tb10197.x

Couper, R. A. (1958): British Mesozoic microspores and pollen grains. A systematic and stratigraphic study. Palaeontographica, Abt. B, 103: 75-179.

Dolezych, M. (2005): Coniferous wood from the Second Lusatian Seam (Brandenburg, Saxony) and their ecological significance; Ph.D. Thesis - MS, University of Utrecht, Utrecht, $339 \mathrm{pp}$.

Dolezych, M., Schneider, W. (2006): Inkohlte Hölzer und Cuticulae dispersae aus dem 2. Miozänen Flözhorizont im Tagebau Welzow (Lausitz) - Taxonomie und vergleichende feinstratigraphisch-fazielle Zuordnung. Zeitschrift für Geologische Wissenschaften, 34: 165-259.

Dörken, V. M., Stützel, T. (2011): Morphology and anatomy of anomalous cladodes in Sciadopitys verticillata Siebold \& Zucc. (Sciadopityaceae). - Trees, 25: 199-213. https://doi.org/10.1007/s00468-010-0498-6

Earle, C. J. (2021): The Gymnosperm Database. https://www.conifers.org [assessed July 2021]

Eckenwalder, J. E. (2009): Conifers of the World: The Complete Reference. - Timber Press Inc., London, 720 pp.

Egger, H., Coric, S. (2017): Erläuterungen zu Blatt 56 St. Pölten. Geologische Karte der Republik Österreich 1 : 50 000. - Geologische Bundesanstalt, Wien, 171 pp.

Farjon, A. (2005): A monograph of Cupressaceae and Sciadopitys. - Royal Botanic Gardens, Kew, 648 pp.

Ferguson, D. K. (1967): On the phytogeography of Coniferales in the European Cenozoic. - Palaeogeography, Palaeoclimatology, Palaeoecology, 3: 73-110. https://doi.org/10.1016/0031-0182(67)90007-7

Figueiral, I., Mosbrugger, V., Rowe, N. P., Ashraf, A. R., Utescher, T., Jones, T. P. (1999): The Miocene peatforming vegetation of northwestern Germany: An analysis of wood remains and comparison with previous palynological interpretations. - Review of Palaeobotany and Palynology, 104: 239-266. https://doi.org/10.1016/S0034-6667(98)00059-1

Fisher, M. J., Dunay, R. E. (1981): Palynology and the Triassic/Jurassic boundary. - Review of Palaeobotany and Palynology, 34: 129-135. https://doi.org/10.1016/0034-6667(81)90070-1

Florin, R. (1922): On the geological history of the Sciadopitineae. A preliminary note. - Svensk Botanisk Tidskrift, 16: 260-270.

Florin, R. (1931): Untersuchungen zur Stammesgeschichte der Coniferales und Cordaitales, 1. Teil: Morphologie und Epidermisstruktur der Assimilationsorgane bei den 
rezenten Koniferen. - Kungliga Svenska Vetenskapsakademiens Handlingar, 10: 1-588.

Florin, R. (1963): The distribution of Conifer and Taxad genera in time and space. - Acta horti Bergiani, 20(4): $121-312$.

Gomez, B. (2002): A new species of Mirovia (Coniferales, Miroviaceae) from the Lower Cretaceous of the Iberian Ranges (Spain). - Cretaceous Research, 23: 761-773. https://doi.org/10.1006/cres.2002.1023

Gothan, W. (1936): Nochmals die 'Graskohle': Nadeln der Schirmtanne (Sciadopitys). - Zeitschrift für Gewinnung und Verwertung der Braunkohle, 35: 736-738.

Gothan, W., Weyland, H. (1973): Lehrbuch der Paläobotanik. - Akademie Verlag, Berlin, 677 pp.

Grimsson, F., Zetter, R. (2011): Combined LM and SEM study of middle Miocene (Sarmatian) palynoflora from the Lavanttal basin, Austria: Part II Pinophyta. - Grana, 50: $262-310$.

https://doi.org/10.1080/00173134.2011.641450

Halle, T. G. (1915): Some xerophytic leaf-structures in Mesozoic plants. - Geologiska Föreningens Förhandlingar, 37: 493-520. https://doi.org/10.1080/11035891509444832

Herngreen, G. F. W., Kedves, M., Rovinina, L. V., Smirnova, S. B. (1996): Cretaceous palynofloral provinces: A review. - In: Jansonius, J., McGregor, D. C. (eds), Palynology: Principles and applications, vol. 3. American Association of Stratigraphic Palynologists Foundation, [Boston], pp. 1157-1188.

Ho, R., Sziklai, O. (1972): On the pollen morphology of Picea and Tsuga species. - Grana, 12: 31-40. https://doi.org/10.1080/00173137209427643

Hofmann, Ch.-Ch., Zetter, R. (2007): Upper Cretaceous pollen flora from the Vilui basin, Siberia: Circumpolar and endemic Aquilapollenites, Manicorpus and Azonia. - Grana, 46: 227-249. https://doi.org/10.1080/00173130701763142

Hofmann, Ch.-Ch., Zetter, R. (2010): Upper Cretaceous sulcate pollen from the Timerdyakh Formation, Vilui Basin, Siberia. - Grana, 49: 170-193. https://doi.org/10.1080/00173134.2010.512364

Hofmann, Ch.-Ch., Zetter, R., Draxler, I. (2002): Pollenund Sporenvergesellschaftungen aus dem Karpatium des Korneuburger Beckens (Niederöstereich). - Beiträge zur Paläontologie, 27: 17-43.

Ichinnorov, N. (2003): Discovery of Early Cretaceous pollen and spores from the Shaazan Govi area, Southeastern Mongolia. - Mongolian Geoscientist, 18: 2-7.

Ilyina [Il'ina], V. I. (1985): Palinologiya yury Sibiri [Jurassic palynology of Siberia] (Trudy, Sibirskoe otdelenie, Institut geologii i geofiziki, Akademiya Nauk SSSR, vyp. 638 [Transactions, Siberian Branch, Institute of Geology and Geophysics, Academy of Sciences of the USSR, vol. 639]). - Nauka, Moskva, 237 pp. (in Russian)

Jurasky, K. A. (1928): Paläobotanische BraunkohlenStudien III. Ein neuer Fund von Sciadopitys (Konif.) in der Braunkohle (Sciadopityoxylon wettsteini n. sp.). Senckenbergiana, 10: 255-264.

Kirchheimer, F. (1934): Über Tsuga-pollen aus dem Tertiär. - Planta, 22(2): 171-179.

https://doi.org/10.1007/BF01916450
Klaus, W. (1987): Einführung in die Paläobotanik. Band 1. Deuticke Verlag, Wien, 314 pp.

Krutzsch, W. (1971): Atlas der Mittel- und Jungtertiären dispersen Sporen und Pollen sowie der Mikroplanktonformen des Nörddlichen Mitteleuropas. - Gustav FischerVerlag, Jena, 232 pp.

Kurmann, M. H. (1992): Exine stratification in extant gymnosperms. A review of published transmission electron micrographs. - Kew Bulletin, 47(1): 25-39. https://doi.org/10.2307/4110766

Kuzmichev, A. B., Danukalova, M. K., Aleksandrova, G. N., Zakharov, V. A, Herman, A. B., Nikitenko, B. L., Khubanov, V. B., Korostylev, E. V. (2018): MidCretaceous Tuor-Yuryakh Section of Kotelnyi Island, New Siberian Islands: How does the probable basement of sedimentary cover of the Laptev Sea Look on Land? - Stratigraphy and Geological Correlation, 26: 403-432. https://doi.org/10.1134/S0869593818040044

Larsson, L. M. (2009): Palynostratigraphy of the TriassicJurassic transition in southern Sweden. - GFF, 131: 147-163. https://doi.org/10.1080/11035890902924828

LePage, B. A. (2003): A new species of Tsuga (Pinaceae) from the middle Eocene of Axel Heiberg Island, Canada, and an assessment of the evolution and biogeographical history of the genus. - Botanical Journal of the Linnean Society, 141: 257-296. https://doi.org/10.1046/j.1095-8339.2003.00131.x

Macko, S. (1957): Lower Miocene pollen flora from the valley of Klodnica near Gliwice (Upper Silesia). Travaux de la Société des Sciences et Lettres de Wroclaw, Ser. B, 88: 1-313.

Mai, D. H. (1995): Tertiäre Vegetationsgeschichte Europas. - Gustav Fischer Verlag, Jena, 691 pp.

Mai, D. H. (1999): The Lower Miocene floras of the Spremberger sequence and the second browncoal horizon in the Lusatica region. Part I: Waterferns, conifers, and monocotyledons. - Palaeontographica, Abt. B, 250: $1-76$.

Mai, D. H. (2000): The Middle and Upper Miocene floras of the Meuro and Rauno sequences in the Lusatia region. Part I: Waterferns, conifers, and monocotyledons. Palaeontographica, Abt. B, 256: 1-68.

Mai, D. H. (2004): The Miocene and Pliocene floras from Northeast-Brandenburg and Southwest-Mecklenburg. Palaeontographica, Abt. B, 269: 1-130.

Manchester, S. R., Chen, Z. D., Lu, A. M., Uemura, K. (2009): Eastern Asian endemic seed plant genera and their paleogeographic history throughout the Northern Hemisphere. - Journal of Systematics and Evolution, 47: $1-42$. https://doi.org/10.1111/j.1759-6831.2009.00001.x

Manum, S. B. (1962): Studies in the Tertiary flora of Spitsbergen, with notes on Tertiary floras of Ellesmere Island, Greenland, and Iceland. - Norsk Polarinstitutt Skrifter, 125: 1-127.

Manum, S. B., Van Konijnenburg-Van Cittert, J. H. A., Wilde, V. (2000): Tritaenia Maegdefrau et Rudolf, Mesozoic 'Sciadopitys-like' leaves in mass accumulations. Review of Palaeobotany and Palynology, 109: 255-269. https://doi.org/10.1016/S0034-6667(99)00058-5 
Menzel, P. (1913): Beitrag zur Flora der Niederrheinischen Braunkohlenformation. - Jahrbuch der Königlich Preußischen Geologischen Landesanstalt zu Berlin, 34: $1-98$.

Nilsson, T. (1958): Über das Vorkommen eines mesozoischen Sapropelgesteins in Schonen. - Lunds Universitets Årsskrift, Ny Följd, Avd. 2, 54(10): 1-112.

Nosova, N. V., Kiritchkova, A. I. (2008): First records of the genus Mirovia Reymanówna (Miroviaceae, Coniferales) from the Lower Jurassic of western Kazakhstan (Mangyshlak). - Paleontological Journal, 42: 1383-1392. https://doi.org/10.1134/S0031030108120022

Nosova, N., Wcisło-Luraniec, E. (2007): A reinterpretation of Mirovia Reymanówna (Coniferales) based on the reconsideration of the type species Mirovia szaferi Reymanówna from the Polish Jurassic. - Acta Palaeobotanica, 47: 359-377.

Ogura, Y. (1932): On the structure and affinities of some Cretaceous plants from Hokkaido, second contribution. - Journal of the Faculty of Science, Imperial University of Tokyo, Sec. III, 2: 455-483.

Ohsawa, T., Nishida, M., Nishida, H. (1991): Structure and affinities of the petrified plants from the Cretaceous of northern Japan and Saghalien IX. Petrified cone of Sciadopitys from the Upper Cretaceous of Hokkaido. Journal of Phytogeography and Taxonomy, 39: 97-105. https://doi.org/10.1007/BF02497661

Philippe, M., Méon, H., Lambert, G., Erdei, B., Thevenard, F., Gomez, B. (2002): A palm-tree and Sciadopitys swamp-forest from the Neogene of Bresse (eastern France). - Comptes Rendus Palevol, 1: 221-225. https://doi.org/10.1016/S1631-0683(02)00035-0

Potonié, R. (1967): Versuch einer Einordnung der fossilen Sporae dispersae in das phylogenetische System der Pflanzenfamilien. 1. Teil Thallophyta bis Gnetales, 2. Teil Angiospermae. - Forschungsberichte des Landes Nordrhein-Westfalen, 1761: 1-310.

Reymanówna, M. (1985): Mirovia szaferi gen. et sp. nov. (Ginkgoales) from the Jurassic of the Kraków region, Poland. - Acta Palaeobotanica, 25(1-2): 3-12.

Rohrmüller, J. (2003): Die Forschungsbohrung Bayerhof - die Erkundung eines Tertiären Maars im Steinwald, Oberpfalz (NE-Bayern). - Geologica Bavarica, 107: 215-220.

Rohrmüller, J., Horn, P. (2003): Ergebnisse der K-ArDatierung einer basaltische Tuffbreccie aus der Bohrung Bayerhof und von Basalten des Umfeldes. - Geologica Bavarica, 107: 227-229.

Sachse, M., Hofmann, Ch.-Ch. (2020): Zur palynologischen Aussagekraft einiger Proben aus der Bohrung Bayerhof - eine Pilotstudie. - Zitteliana, 94: 85-97. https://doi.org/10.5282/ubm/epub.75980

Sadowski, E.-M., Schmidt, A. R., Kunzmann, L., Gröhn, C., Seyfullah, L. J. (2016): Sciadopitys cladodes from Eocene Baltic amber. - Botanical Journal of the Linnean Society, 180: 258-268. https://doi.org/10.1111/boj.12365

Saiki, K. (1992): A new sciadopityaceous seed cone from the Upper Cretaceous of Hokkaido, Japan. - American Journal of Botany, 79: 989-995.

https://doi.org/10.1002/j.1537-2197.1992.tb13688.x
Schneider, W. (1992): Floral succession in Miocene swamps and bogs of Central Europe. - Zeitschrift für Geologische Wissenschaften, 20: 555-570.

Schneider, W. (2004): A leaf-bearing taphocoenosis in the 2nd Miocene seam from Nochten (Lusatia): taxonomy, taphonomy and phytostratigraphy. - Palaeontographica, Abt. B, 268: 1-74.

Schneider, W. (2008): Retinit und Bernstein als Komponenten phytogener Taphocoenosen in Kohlenflözen und kohligen Begleitschichten. - Exkursionsführer und Veröffentlichungen der Deutschen Gesellschaft für Geowissenschaften, 236: 77-87.

Schulz, E. (1967): Sporenpaläontologische Untersuchungen rätoliassischer Schichten im Zentralteil des Germanischen Beckens. - Paläontologische Abhandlungen, B, 2(3): 541-633.

Shang, Y., Zavada, M. S. (2003): The ultrastucture of Cerebropollenites from the Jurassic and Cretaceous of Asia. - Grana, 42: 102-107.

https://doi.org/10.1080/00173130310009020

Spicer, R. A., Ahlberg, A., Herman, A. B., Hofmann, Ch.-Ch., Raikevich, M. I., Valdes, P. J., Markwick, P. J. (2008): The Late Cretaceous continental interior of Siberia: A challenge for Climate Models. - Earth and Planetary Science Letters, 267: 228-235. https://doi.org/10.1016/j.epsl.2007.11.049

Srivastava, S. K., Rouse, G. E. (1970) Systematic revision of Aquilapollenites Rouse. - Canadian Journal of Botany, 48(9): 1591-1601. https://doi.org/10.1139/b70-235

Stuchlik, L., Ziembińska-Tworzydło, M., KohlmanAdamska, A., Grabowska, I., Ważyńska, H., Sadowska, A. (2002): Atlas of pollen and spores of the Polish Neogene, Vol. 2 - Gymnosperms. - W. Szafer Institute of Botany, Polish Academy of Sciences, Kraków, $237 \mathrm{pp}$.

Surova, T. D., Kvavadze, E. V. (1988): Ul'trastruktura sporodemy nekotorykh golosemennykh (Metasequoia, Cunninghamia, Sciadopitys) [Sporoderm Ultrastructure in some gymnosperms (Metasequoia, Cunninghamia, Sciadopitys)]. - Botanicheskii Zhurnal, 73: 34-44. (in Russin with English summary)

Takahashi, M. (1997): Fossil spores and pollen grains of Cretaceous (Upper Campanian) from Sakhalin, Russia. Journal of Plant Research, 110: 283-298. https://doi.org/10.1007/BF02509317

Thiergart, F. (1949): Die Sciadopitys-Zone und der Sciadopitys-Vorstoß in der niederrheinischen Braunkohle. Braunkohle, Wärme und Energie, 1: 153-156.

Tsukada, M. (1963): Umbrella pine, Sciadopitys verticillata: past and present distribution in Japan. - Science, 142: 1680-1681. https://doi.org/10.1126/science.142.3600.1680

Uemura, K. (1986): A note of Tertiary Sciadopitys (Coniferopsida) from Japan. - Bulletin of the National Science Museum Tokyo, Ser. C, 12: 53-59.

Uehara, K., Saiki, K. (2011): Pollen wall development in Sciadopitys verticillata (Sciadopityaceae). - Plant Systematics and Evolution, 294: 177-183. https://doi.org/10.1007/s00606-011-0449-8 
Ueno, J. (1951): Morphology of pollen of Metasequoia, Sciadopitys and Taiwania. - Journal of the Institute of Polytechnics, Osaka City University, D, 2: 22-28.

Vissher, H., Brugman, W. A. (198): Ranges of selected palynomorphs in the Alpine Triassic of Europe. - Review of Palaeobotany and Palynology, 34: 115-128. https://doi.org/10.1016/0034-6667(81)90069-5

Waksmundzka, M. (1981): Palynological analysis of Lower Cretaceous sediments from Kujawy (Poland). - Acta Palaeontologica Polonica, 26: 257- 280.

Weyland, H., Kilpper, K., Berendt, W. (1967): Kritische Untersuchungen zur Kutikularanalyse tertiärer Blätter
VII. Nachträge zu früheren Arbeiten über Epidermen aus der niederrheinischen Braunkohle und neue Arten. Palaeontographica, Abt. B, 120: 151-168.

Wolfe, A. P., Tappert, R., Muehlenbachs, K., Boudreau, M., McKellar, R. C., Basinger, J. F., Garrett, A. (2009): A new proposal concerning the botanical origin of Baltic amber. - Proceedings of the Royal Society, B: Biological Sciences, 276: 3403-3412.

https://doi.org/10.1098/rspb.2009.0806 